\title{
Micropropagation of Members of the Cactaceae Subtribe Cactinae
}

\author{
Philip W. Clayton', John F. Hubstenberger, and Gregory C. Phillips ${ }^{2}$ \\ Department of Agronomy and Horticulture, New Mexico State University, Las Cruces, NM 88003- \\ 0003
}

\author{
S. Ann Butler-Nance \\ Department of Experimental Statistics, New Mexico State University, Las Cruces, NM 88003-0003
}

Additional index words. cactus, in vitro, Escobaria, Mamillaaria, Pediocactus, Sclerocactus, Toumeya

\begin{abstract}
Micropropagation of 11 rare or endangered cacti species belonging to the subtribe Cactinae was achieved by rooting of proliferated axillary shoots. Shoot tip explants were obtained from seedlings of Escobaria missouriensis D.R. Hunt, E. robbinsorum (Earle) D.R. Hunt, Sclerocactus spinosior (Engelm.) Woodruff \& L. Benson, and Toumeya papyracantha (Engelm.) Br. \& Rose, and from mature plants of Mammillaria wrightii Engelm., Pediocactus bradyi L. Benson, $P$. despainii Welsh \& Goodrich, $P$. knowltonii L. Benson, P. paradinei B.W. Benson, P. winkleri Heil, and S. mesae-verdae (Boissevain) L. Benson. Three or four species were used in each of a series of experiments investigating the effects of basal media and auxin and cytokinin types and concentrations on axillary shoot proliferation. Low or no auxin but moderate to high cytokinin concentrations were required for axillary shoot production. All species rooted spontaneously on hormone-free media; however, several species rooted better on media containing auxin. All species were re-established in the greenhouse.
\end{abstract}

The propagation of native cacti is usually done with seed and rooted offshoots; however, conventional propagation methods are inadequate for those species that exhibit no to few offshoots, seed dormancy, low germination rates, self-sterility, slow growth, or that require many years to mature. These difficulties are compounded by the limited availability of species that are threatened with extinction.

Tissue culture techniques can overcome certain limitations associated with conventional propagation of rare cacti. The establishment of callus cultures from several genera of cacti (King, 1957; Minocha and Mehra, 1974; Havel and Kolar, 1983) and studies on morphogenesis (Mauseth and Halperin, 1975; Kolar et al., 1976; Johnson and Emino, 1979a) have been reported. At least 24 species of cacti from 16 genera have been micropropagated by rooting of shoots proliferated through axillary branching (Mauseth, 1979; Johnson and Emino, 1979b; Vyskot and Jara, 1984; Starling, 1985; Ault and Blackmon, 1985, 1987; Escobar et al., 1986; Rubluo et al., 1986). Cacti micropropagated through axillary branching have shown a high degree of phenotypic uniformity within clones (Mauseth, 1979; Ault and Blackmon, 1987).

Of the cacti investigated in the present report, only Pediocactus paradinei has been evaluated previously for micropropagation potential. Successful in vitro axillary shoot proliferation and rooting were reported, but it is not clear whether plants were successfully re-established (Sluis and Wochok, 1980).

The objective of this investigation was to evaluate basal medium composition and requirements for hormone types, concentrations, and combinations for axillary shoot proliferation of 11 species of rare (Escobaria missouriensis, Mammillaria wrightii, Sclerocactus spinosior), candidate (Pediocactus des-

Received for publication 23 Nov. 1988. Journal article no. 1439 of the New Mexico Agricultural Experiment Station. Research supported in part by DOI Cooperative Agreement 14-16-0002-86-916. The cost of publishing this paper was defrayed in part by the payment of page charges. Under postal regulations, this paper therefore must be hereby marked advertisement solely to indicate [his fact.

'Present address: U.S. Fish and Wildlife Service, c/o Corpus Christi State Univ. Campus Box 338, Corpus Christi, TX 78412.

'To whom reprint requests should be addressed. painii, P. paradinei, P. winkleri, Toumeya papyracantha), threatened (E. robbinsorum, S. mesae-verdae), or endangered (P. bradyi, $P$. knowltonii) cacti. These cactus species are difficult to grow and are valued as collector's items. In addition, the potential for root development and plantlet re-establishment of these 11 species was assessed.

\section{Materials and Methods}

Initiation of cultures. A few mature plant specimens of $\mathrm{M}$. wrightii, $P$. bradyi, $P$. despainii, $P$. knowltonii, $P$. paradinei, $P$. winkleri, and S. mesae-verdae provided shoot tip explants from primary or secondary stems. Excised shoot tips 1 to $2 \mathrm{~cm}$ in diameter were immersed in $95 \%$ ethanol for 1 rein, $2 \%$ sodium hypochlorite (diluted commercial bleach) for 7 rein, and rinsed three times in sterile water. Seeds of E. missouriensis, E. robbinsorum, S. spinosior, and T. papyracantha were surface-sterilized by the same procedure and germinated in vitro on hormone-free MS medium (Murashige and Skoog, 1962). Shoot tip explants $=0.5 \mathrm{~cm}$ in diameter ( 2 to 6 months old) were excised. Explants were inoculated onto MS media containing one or more of the following combinations of hormonal supplements to initiate tissue cultures: $24.6 \mu \mathrm{M} \mathrm{N}$-(methyl-2butenyl)- $1 \mathrm{H}$-purin-6-amine (2iP) + $0.15 \mathrm{~mm} 1 \mathrm{H}$-purin-6-amine (adenine sulfate); $11.4 \mu \mathrm{m} 1 \mathrm{H}$-indole-3-acetic acid (IAA) + $18.6 \mu \mathrm{M} \mathrm{N}$-(2-furanylmethyl)-1H-purin-6-amine (kinetin) + 0.30 mM adenine sulfate; $0.3 \mu \mathrm{m}$ l-naphthaleneacetic acid (NAA) $+4.4 \mu \mathrm{M} \mathrm{N}$-(phenylmethyl)-1H-purin-6-amine (BA); and 4.9 $\mu \mathrm{M} 1 \mathrm{H}$-indole-3-butyric acid (IBA) $+49.2 \mu \mathrm{M} 2 \mathrm{iP}$. All media contained vitamins according to the L2 formulation of Phillips and Collins (1979), $87.6 \mathrm{~mm}$ sucrose and $8 \mathrm{~g}$ agar/liter (Carolina Biological, Burlington, N. C., plant tissue culture type). Cultures were transferred to fresh media every 4 weeks for proliferation of axillary shoots. To minimize potential carryover effects, these stock cultures were standardized by serial subculture on a common medium composition for 3 months before beginning each formal experiment. All cultures were grown in $100 \times 25$ $\mathrm{mm}$ polystyrene petri dishes and were incubated at $29 \pm 1 \mathrm{C}$ under continuous fluorescent light $\left(150 \mu \mathrm{mol} \cdot \mathrm{s}^{-1} \cdot \mathrm{m}^{-2}\right)$.

Experiments evaluating individual factors. The first three formal experiments evaluated basal medium formulations, auxin 
type and concentrations, or cytokinin type and concentrations as individual factors using a randomized complete block design. Three or four species were selected for each experiment, depending on the availability of shoots for inoculation. Four shoots (replications) of each species were inoculated into a petri dish, with four dishes (blocks) per treatment At each monthly subculture, only newly developed axillary shoots were transferred to fresh medium (four per dish). In all experiments that evaluated axillary shoot production, data were collected monthly just before subculture on the number of axillary shoots per explant, for each of three consecutive months. Analyses of variance were calculated for each experiment over 3 months of data (SAS, 1982). Means were separated using the least significant difference test at $P=0.05$. In addition, observations were made on shoot quality and callus production.

The first experiment compared the basal salts of L2, MS, SH (Schenk and Hildebrandt, 1972), B5 (Gamborg et al., 1968) as modified by Dunstan and Short (1977), and a modified halfstrength major salts version of MS (MMS), as described by Gladfelter and Phillips (1987). All media contained the organic supplements as described above, supplemented with $11.4 \mu \mathrm{M}$ $\mathrm{IAA}+18.6 \mu \mathrm{M}$ kinetin $+0.30 \mathrm{~mm}$ adenine sulfate. E. missouriensis, P. bradyi, P. knowltonii, and S. spinosior were used in this experiment and had been grown on the MS version of this medium before beginning the experiment.

The second experiment evaluated auxin type and concentrations, using $\mathrm{MS}+24.6 \mu \mathrm{M} 2 \mathrm{iP}+0.15 \mathrm{~mm}$ adenine sulfate as the control, with nine additional treatments comparing 4amino-3,5,6-trichloro-2-pyridinecarboxylic acid (picloram) (82.8 $\mathrm{nM}$ and $0.8 \mu \mathrm{M})$, IAA $(1.1$ and $11.4 \mu \mathrm{M})$, IBA (1.0 and 9.8 $\mu \mathrm{M})$, and NAA $(0.1,1.1$, and $10.7 \mu \mathrm{M})$. P. bradyi, P. knowltonii, and $S$. spinosior were used in this experiment and had been grown on the control medium before the experiment.

The third experiment evaluated cytokinin type and concentrations using MS basal medium. Two treatments compared adenine sulfate as a supplement in the absence of auxin, i.e., 23.2 $\mu \mathrm{M}$ kinetin $+0.30 \mathrm{~mm}$ adenine sulfate and $23.2 \mu \mathrm{M}$ kinetin alone. Ten additional treatments compared kinetin (23.2 and $46.4 \mu \mathrm{M}), \mathrm{BA}(0.9$ and $4.4 \mu \mathrm{M})$, 2-methyl-4-( 1H-purin-6-ylamino)-2-buten-1-ol (zeatin) (4.6 and $22.8 \mu \mathrm{M}$ ), and 2iP (1.0, 4.9, 24.6, and 49.2 $\mu \mathrm{M})$, all in combination with $11.4 \mu \mathrm{M} \mathrm{IAA} \mathrm{+}$ $0.30 \mathrm{~mm}$ adenine sulfate. $P$. bradyi, $P$. knowltonii, $S$. spinosior and $T$. papyracantha were used in this experiment and had been grown on hormone-free MS medium before beginning the experiment.

Experiments evaluating combinations of factors. The next two experiments evaluated combinations of basal medium, auxin, and cytokinin using a completely randomized design with 16 replications (four explants per dish with four dishes per treatment). Donor stock cultures were grown on hormone-free MS medium before either experiment was begun, and data were collected for each of 3 consecutive months.

The fourth experiment tested seven treatment combinations of the most effective auxin and cytokinin types at concentrations identified in the previous experiments, using the L2 basal medium supplemented with $0.30 \mathrm{~mm}$ adenine sulfate. Picloram at $82.8 \mathrm{nM}, \mathrm{NAA}$ at $1.1 \mu \mathrm{M}$, and auxin-free combinations were tested with zeatin at 22.8 and $45.6 \mu \mathrm{M}$ or kinetin at 23.2 and $46.4 \mu \mathrm{M}$. M. wrightii, P. despainii, P. winkleri, and S. mesaeverdae were used in this experiment.

The fifth experiment tested six treatment combinations of L2 or MS basal media, both supplemented with $0.30 \mathrm{~mm}$ adenine sulfate, with either zeatin at $45.6 \mu \mathrm{M}$ or BA at $44.4 \mu \mathrm{M}$, and with either picloram at $82.8 \mathrm{~nm}$ or NAA at $1.1 \mu \mathrm{M}$. E. robbinsorum, $P$. bradyi, $P$. paradine $i$, and $T$. papyracantha were used in this experiment.

Rooting and re-establishment of plants. Axillary shoots (1 to $2 \mathrm{~cm}$ in height) obtained from these experiments were placed on hormone-free MS and on MS supplemented with picloram $(0.8 \mu \mathrm{M})$, IAA $(11.4,28.5$, or $57.1 \mu \mathrm{M})$, IBA $(9.8,24.6$, or $49.2 \mu \mathrm{M})$, and/or NAA $(10.7,26.9$, or $53.7 \mu \mathrm{M})$ for induction of roots. Rooted shoots were transferred to hormone-free MS for continued development after 1 month of exposure to auxin. Rooting frequencies were tabulated at the end of 3 months of incubation. Plantlets 2 to $5 \mathrm{~cm}$ in height were transplanted into a pasteurized soil mix of native sand, native loam, and sphagnum peat. Survival rates were scored after 3 months of growth in the greenhouse.

\section{Results}

In these experiments, certain treatments produced distorted cactus shoots with abnormal symmetry and spination, or stimulated callus production. However, the most effective treatments demonstrated good shoot quality and minimal callus production. An ideal axillary shoot proliferation response with no attendant callus production is illustrated for $P$. knowltonii (Fig. 1).

Basal medium study. The analysis of variance for this experiment indicated that the block effect and the basal medium $\times$ species interaction were not significant for axillary shoot proliferation; however, the main effects of basal medium and of species were significant (Table 1). Treatment means were presented for the main effects of the data averaged over the 3 months of the experiment (Table 1). Of the five basal media tested, the L2 medium proved most effective, yielding an average of 5.5 axillary shoots per explant cultured each passage. The MS, SH, and B5 media were comparable for axillary shoot proliferation, while the MMS version containing half-strength

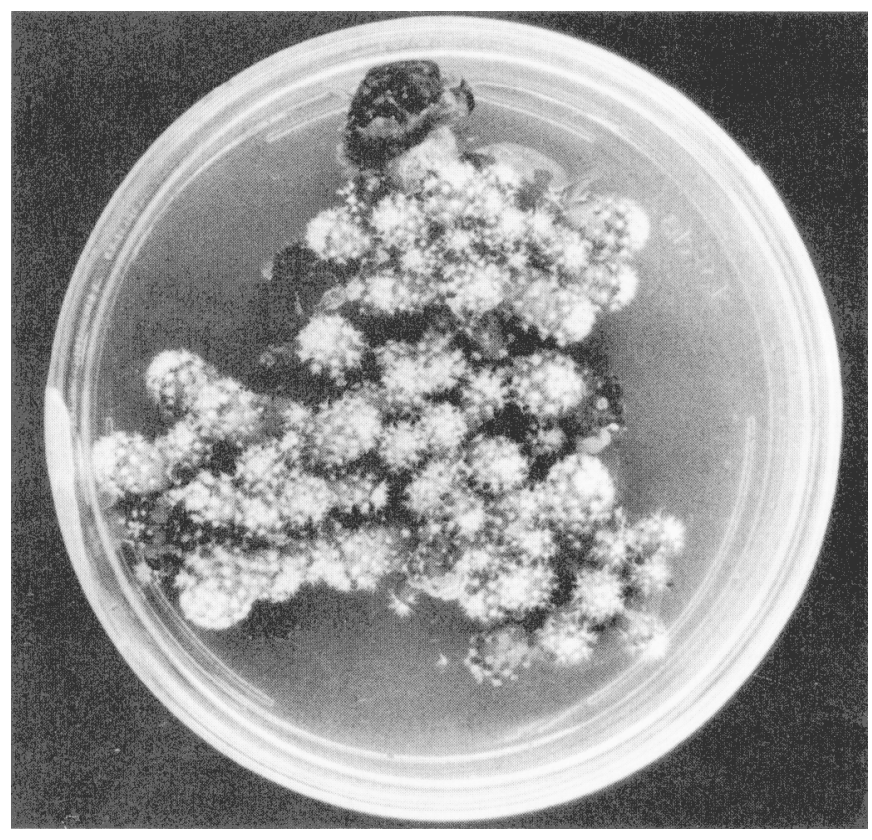

Fig. 1. Axillary shoot proliferation of Pediocactus knowltonii on MS medium $+22.8 \mu \mathrm{M}$ zeatin $+11.4 \mu \mathrm{M}$ IAA $+0.30 \mathrm{mM}$ adenine sulfate. 
Table 1. Effect of five basal nutrient media on shoot production of four species of cacti during 3 months following micropropagation.

\begin{tabular}{|c|c|c|c|c|c|}
\hline \multirow[b]{2}{*}{$\begin{array}{l}\text { Basal } \\
\text { medium } \\
\text { treatment }\end{array}$} & \multicolumn{5}{|c|}{ Mean shoot number per monthly passage } \\
\hline & $\begin{array}{c}\text { Esco- } \\
\text { baria } \\
\text { missouri- } \\
\text { ensis }\end{array}$ & $\begin{array}{l}\text { Pedio- } \\
\text { cactus } \\
\text { bradyi }\end{array}$ & $\begin{array}{c}\text { Pedio- } \\
\text { cactus } \\
\text { knowltonii }\end{array}$ & $\begin{array}{l}\text { Sclero- } \\
\text { cactus } \\
\text { spino- } \\
\text { sior }\end{array}$ & $\begin{array}{c}\text { Treatment } \\
\text { means }^{\mathrm{y}}\end{array}$ \\
\hline L2 & 6.7 & 5.9 & 3.6 & 5.8 & $5.5 \mathrm{a}$ \\
\hline SH & 5.7 & 5.8 & 2.9 & 4.5 & $4.7 \mathrm{~b}$ \\
\hline B5 & 6.7 & 4.5 & 3.7 & 2.8 & $4.4 \mathrm{~b}$ \\
\hline MS & 6.3 & 4.4 & 2.1 & 3.6 & $4.1 \mathrm{~b}$ \\
\hline MMS • & 4.6 & 2.0 & 1.3 & 2.2 & $2.5 \mathrm{c}$ \\
\hline Species means ${ }^{y}$ & $6.0 \mathrm{a}$ & $4.5 \mathrm{~b}$ & $2.7 \mathrm{~d}$ & $3.8 \mathrm{c}$ & \\
\hline \multicolumn{2}{|c|}{ Source of variation } & df & \multicolumn{2}{|c|}{ Mean squares } & $F$ value \\
\hline \multicolumn{2}{|c|}{ Block } & 3 & \multicolumn{2}{|c|}{5.63} & $1.10^{\mathrm{NS}}$ \\
\hline \multicolumn{2}{|l|}{ Basal medium } & 4 & \multicolumn{2}{|c|}{85.70} & $16.80^{* * *}$ \\
\hline \multicolumn{2}{|c|}{ Species } & 4 & \multicolumn{2}{|c|}{114.42} & $22.44 * * *$ \\
\hline \multicolumn{2}{|c|}{ Basal medium $\times$ species } & 16 & \multicolumn{2}{|c|}{7.04} & $1.38^{\mathrm{NS}}$ \\
\hline \multicolumn{2}{|c|}{ Error } & 71 & \multicolumn{2}{|c|}{5.10} & \\
\hline
\end{tabular}

${ }^{2}$ All media included $11.4 \mu \mathrm{M} \mathrm{IAA}+18.6 \mu \mathrm{M}$ kinetin $+0.30 \mathrm{mM}$ adenine sulfate. L2 = Phillips and Collins (1979); $\mathrm{SH}=$ Schenk and Hildebrandt (1972); B5 = Gamborg et al. (1968) as modified by Dunstan and Short (1977); MS = Murashige and Skoog (1962); MMS = MS as modified by Gladfelter and Phillips (1987).

yValues followed by different letters within a column or within a row differ at $P \leq 0.05$.

Ns, "Nonsignificant at $P \leq 0.05$ or significant at $P \leq 0.001$, respectively.

major salts proved least effective. The slowest-growing cactus, $P$. knowltonii, showed the lowest rate of axillary shoot production, while the fastest-growing cactus, E. missouriensis, showed the greatest production of axillary shoots.

Axin effects. The analysis of variance for this experiment indicated the block effect was not significant, but the main effects of auxin treatment and species and the interaction of auxin and species were significant (Table 2). Auxin treatment means were separated within species for data averaged over 3 months (Table 2). Two of the species showed discrimination for auxin type; e.g., NAA was a suitable auxin source for P. knowltonii, but not for S. spinosior, while IAA was a suitable auxin for S. spinosior, but not for P. knowltonii. P. bradyi performed well on one concentration of each of the auxin types. The auxin-free treatment and the treatments including $82.8 \mathrm{~nm}$ picloram or 1.0 $\mu \mathrm{M}$ IBA were equally effective with all three species.

Cytokinin effects. The analysis of variance for this experiment indicated the block effect was not significant, but the main effects of cytokinin treatments and species and their interaction were significant (Table 3). Cytokinin treatment means were separated within species for data averaged over the 3-month duration of the experiment. For the species evaluated, high concentrations of cytokinin (i.e., 22.8 to $49.2 \mu \mathrm{M}$ ) proved most effective. All four species performed optimally on the medium that included $22.8 \mu$ m zeatin. Only $P$. bradyi responded to BA at one of the concentrations tested. Kinetin at $46.4 \mu \mathrm{M}$ was suitable for $P$. bradyi and $S$. spinosior axillary shoot proliferation. The 23.2- $\mu \mathrm{M}$ kinetin treatment was compared with and without auxin (IAA at $11.4 \mu \mathrm{M}$ ); $S$. spirrosior showed a definitely better response to auxin with this cytokinin. The auxinfree version of this cytokinin treatment was compared with and without adenine sulfate as a supplement; $P$. bradyi produced more axillary shoots in the presence of adenine sulfate, but $S$. spinosior yielded more in the absence of adenine sulfate.
Table 2. Effect of four auxin types on shoot production of three species of cacti during 3 months following micropropagation.

\begin{tabular}{|c|c|c|c|c|c|}
\hline & & \multicolumn{4}{|c|}{ Mean shoot number per monthly passagey } \\
\hline \multicolumn{2}{|c|}{ Auxin $^{\mathbf{z}}$} & \multirow{2}{*}{$\begin{array}{l}\text { Pedio- } \\
\text { cactus } \\
\text { bradyi }\end{array}$} & \multirow{2}{*}{$\begin{array}{c}\text { Pedio- } \\
\text { cactus } \\
\text { knowltonii }\end{array}$} & \multirow{2}{*}{$\begin{array}{l}\text { Sclero- } \\
\text { cactus } \\
\text { spino- } \\
\text { sior }\end{array}$} & \multirow[b]{2}{*}{$\begin{array}{c}\text { Treatmen } \\
\text { means }\end{array}$} \\
\hline Compound & $\begin{array}{l}\text { Concn } \\
(\mu \mathrm{M})\end{array}$ & & & & \\
\hline \multirow[t]{2}{*}{ Picloram } & 0.8 & $0.6 \mathrm{~d}$ & $0.0 \mathrm{~d}$ & $0.9 \mathrm{~d}$ & 0.5 \\
\hline & 0.0828 & $2.5 \mathrm{abc}$ & $1.8 \mathrm{ab}$ & $2.6 \mathrm{a}$ & 2.3 \\
\hline \multirow[t]{3}{*}{ NAA } & 10.7 & $1.6 \mathrm{c}$ & $0.4 \mathrm{~cd}$ & $1.1 \mathrm{~cd}$ & 1.0 \\
\hline & 1.1 & $2.2 \mathrm{abc}$ & $1.8 \mathrm{ab}$ & $1.4 \mathrm{bcd}$ & 1.8 \\
\hline & 0.1 & $2.1 \mathrm{bc}$ & $2.1 \mathrm{a}$ & $1.2 \mathrm{~cd}$ & 1.8 \\
\hline \multirow[t]{2}{*}{ IBA } & 9.8 & $1.9 \mathrm{bc}$ & $1.8 \mathrm{ab}$ & $1.0 \mathrm{~d}$ & 1.6 \\
\hline & 1.0 & $2.6 \mathrm{ab}$ & $1.5 \mathrm{ab}$ & $2.0 \mathrm{abc}$ & 2.0 \\
\hline \multirow[t]{2}{*}{ IAA } & 11.4 & $3.1 \mathrm{a}$ & $1.1 \mathrm{bc}$ & $2.3 \mathrm{ab}$ & 2.1 \\
\hline & 1.1 & $1.6 \mathrm{c}$ & $0.9 \mathrm{bcd}$ & $2.0 \mathrm{abc}$ & 1.5 \\
\hline \multirow{2}{*}{\multicolumn{2}{|c|}{$\begin{array}{l}\text { None } \\
\text { Species means }\end{array}$}} & $2.9 \mathrm{ab}$ & $1.8 \mathrm{ab}$ & $2.8 \mathrm{a}$ & 2.5 \\
\hline & & 2.1 & 1.3 & 1.7 & \\
\hline \multicolumn{3}{|c|}{ Source of variation } & Mea & Mean squares & $F$ value \\
\hline \multicolumn{2}{|c|}{ Block } & & 3 & 3.78 & $1.92^{\mathrm{NS}}$ \\
\hline \multicolumn{2}{|c|}{ Auxin treatment } & & \multicolumn{2}{|c|}{17.05} & $8.65^{* * *}$ \\
\hline \multicolumn{2}{|c|}{ Species } & & \multicolumn{2}{|c|}{23.80} & $12.08 * * *$ \\
\hline \multicolumn{3}{|c|}{ Auxin treatment $\times$ species } & \multicolumn{2}{|c|}{3.40} & $1.73^{*}$ \\
\hline \multicolumn{2}{|c|}{ Error } & & 87 & 1.97 & \\
\hline
\end{tabular}

${ }^{\mathrm{z}}$ Auxin $+24.6 \mu \mathrm{M} 2 \mathrm{iP}+0.15 \mathrm{mM}$ adenine sulfate $+\mathrm{MS}$ basal medium.

y Values followed by different letters within a column differ at $P \leq$ 0.05 .

NS,,$" * *$ Nonsignificant or significant at $P \leq 0.05$ or 0.001 , respectively.

Experiments evaluating combinations of factors. The fourth experiment further evaluated the interaction of auxin and cytokinin in cactus axillarv shoot proliferation. Three auxin treatments and two cytokinin treatments identified in the previous experiments, plus a higher concentration of zeatin, were tested in combinations using the L2 basal medium. The analysis of variance for this experiment indicated the main effects of hormone treatments and species and their interaction effects were significant (Table 4). Hormone treatment means were separated within species averaged over the 3 months of the experiment, illustrating the strong interaction of species with hormone treatments. There was no single hormone treatment that proved optimal for all four species tested, but each treatment proved effective with at least one species. Treatments that included $22.8 \mu \mathrm{M}$ zeatin with or without 1.1 $\mu \mathrm{M}$ NAA were most effective for the majority of the species.

The fifth experiment further evaluated the interaction of basal medium with hormone treatments. The MS and L2 media were tested in combinations with two auxin treatments and two cytokinin treatments. The analysis of variance for this experiment indicated the main effects of media and species and their interaction effects were significant (Table 5). Media means were separated within species for data averaged over 3 months. The use of either L2 or MS medium that included $45.6 \mu \mathrm{M}$ zeatin $+1.1 \mu \mathrm{M}$ NAA proved optimal for axillary shoot production from all four species.

Rooting and re-establishment of micropropagated cacti. After termination of the shoot multiplication experiments, axillary shoots were collected and evaluated for rooting and re-establishment potential. The varied histories and treatments to which these shoots had been exposed appeared to influence the subsequent rooting and re-establishment responses. Therefore, only general observations were made with respect to the rooting and re-es- 
Table 3. Effect of four cytokinin types and adenine sulfate on shoot production of four species of cacti during 3 months following micropropagation.

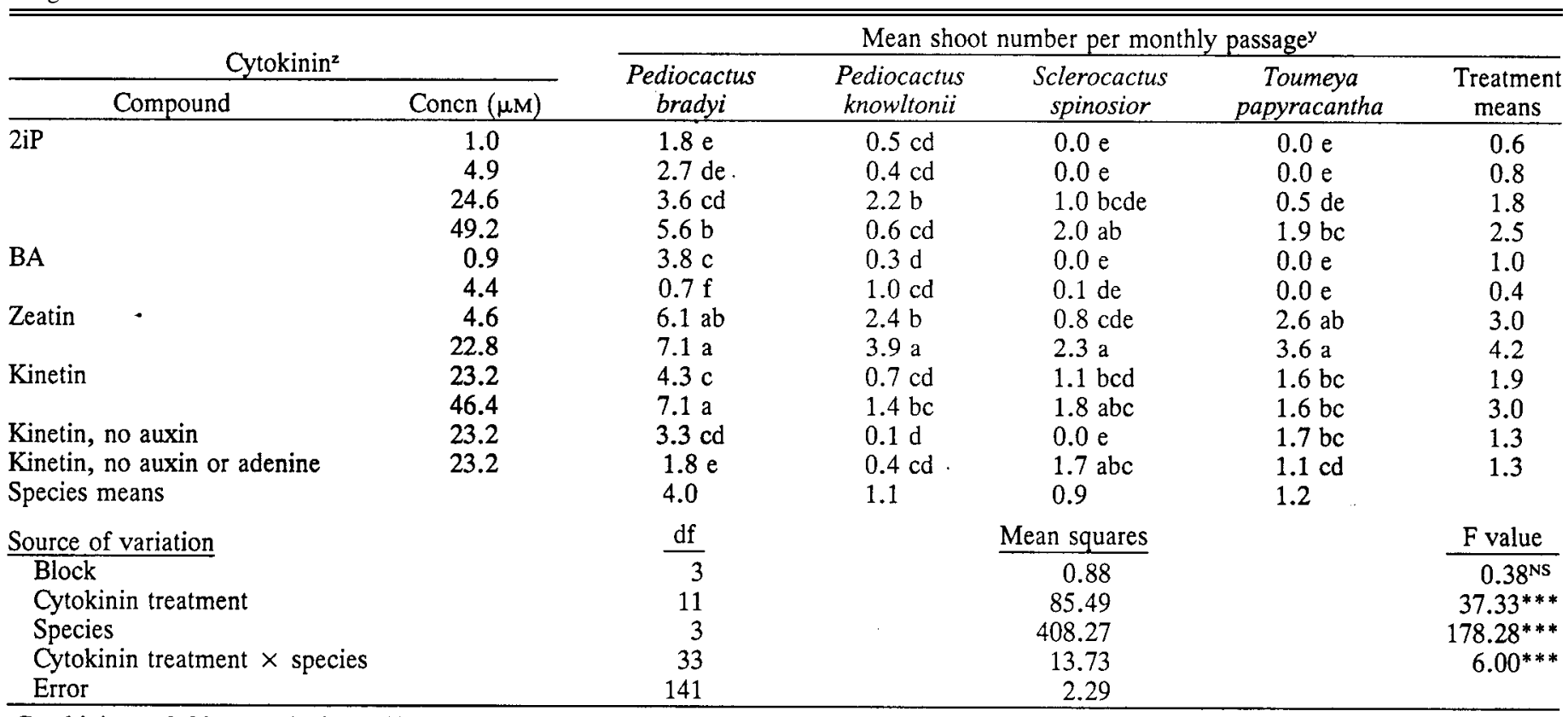

${ }^{2}$ Cytokinin $+0.30 \mathrm{mM}$ adenine sulfate $+11.4 \mu \mathrm{M}$ IAA + MS basal medium, except as indicated.

y Values followed by different letters within a column differ at $P \leq 0.05$.

Ns, “- Nonsignificant at $P \leq 0.05$ or significant at $P \leq 0.001$, respectively.

Table 4. Effect of combinations of auxins and cytokinins on shoot production of four species of cacti during 3 months following micropropagation.

\begin{tabular}{|c|c|c|c|c|c|c|}
\hline \multirow{2}{*}{\multicolumn{2}{|c|}{ Auxin and cytokinin ${ }^{z}$}} & \multicolumn{5}{|c|}{ Mean shoot number per monthly passagey } \\
\hline & & \multirow{2}{*}{$\begin{array}{c}\text { Mammillaria } \\
\text { wrightii }\end{array}$} & \multirow{2}{*}{$\begin{array}{l}\text { Pediocactus } \\
\text { despainii }\end{array}$} & \multirow{2}{*}{$\begin{array}{c}\text { Pediocactus } \\
\text { winkleri }\end{array}$} & \multirow{2}{*}{$\begin{array}{l}\text { Sclerocactus } \\
\text { mesae-verdae }\end{array}$} & \multirow{2}{*}{$\begin{array}{c}\text { Treatment } \\
\text { means }\end{array}$} \\
\hline Compounds & Concn $(\mu \mathrm{M})$ & & & & & \\
\hline Picloram & $0.0828+$ & & \multirow{3}{*}{$3.4 \mathrm{~d}$} & \multirow{3}{*}{$9.8 \mathrm{a}$} & \multirow{3}{*}{$1.0 \mathrm{~d}$} & \multirow{3}{*}{4.5} \\
\hline Zeatin & 45.6 & \multirow[t]{2}{*}{$4.0 \mathrm{a}$} & & & & \\
\hline Picloram & $0.0828+$ & & & & & \\
\hline Kinetin & 46.4 & \multirow[t]{2}{*}{$0.6 \mathrm{~b}$} & \multirow[t]{2}{*}{$4.4 \mathrm{~cd}$} & \multirow[t]{2}{*}{$4.6 \mathrm{c}$} & \multirow[t]{2}{*}{$4.3 \mathrm{a}$} & \multirow[t]{2}{*}{3.5} \\
\hline NAA & $1.1+$ & & & & & \\
\hline Zeatin & 22.8 & \multirow[t]{2}{*}{$3.8 \mathrm{a}$} & \multirow[t]{2}{*}{$6.5 \mathrm{ab}$} & \multirow[t]{2}{*}{$6.9 \mathrm{~b}$} & \multirow[t]{2}{*}{$3.0 \mathrm{abc}$} & \multirow[t]{2}{*}{5.1} \\
\hline NAA & $1.1+$ & & & & & \\
\hline Zeatin & 45.6 & \multirow[t]{2}{*}{$2.9 \mathrm{a}$} & \multirow[t]{2}{*}{$5.2 \mathrm{bc}$} & \multirow[t]{2}{*}{$6.9 \mathrm{~b}$} & \multirow[t]{2}{*}{$1.4 \mathrm{~cd}$} & \multirow[t]{2}{*}{4.1} \\
\hline NAA & $1.1+$ & & & & & \\
\hline Kinetin & 46.4 & \multirow[t]{2}{*}{$0.7 \mathrm{~b}$} & \multirow[t]{2}{*}{$4.4 \mathrm{~cd}$} & \multirow[t]{2}{*}{$4.0 \mathrm{c}$} & \multirow[t]{2}{*}{$3.2 \mathrm{ab}$} & \multirow[t]{2}{*}{3.1} \\
\hline No auxin + & & & & & & \\
\hline Zeatin & 22.8 & \multirow[t]{2}{*}{$3.3 \mathrm{a}$} & \multirow[t]{2}{*}{$6.9 \mathrm{a}$} & $8.6 \mathrm{a}$ & $2.7 \mathrm{BC}$ & 5.4 \\
\hline No auxin + & & & & & & \\
\hline Zeatin & 45.6 & $3.8 \mathrm{a}$ & $3.3 \mathrm{~d}$ & $6.5 \mathrm{~b}$ & $0.4 \mathrm{~d}$ & 3.5 \\
\hline Species means & & 2.7 & 4.9 & 6.8 & 2.3 & \\
\hline Source of varia & & & & Mean squa & & $F$ value \\
\hline Hormone tre & & & & 48.08 & & $9.12^{* * *}$ \\
\hline Species & & & & 477.53 & & $90.61 * * *$ \\
\hline Hormone tre & $\times$ species & & & 39.19 & & $7.44^{* * *}$ \\
\hline Error & & & & 5.27 & & \\
\hline
\end{tabular}

${ }^{2}$ Auxin + cytokinin $+0.30 \mathrm{~mm}$ adenine sulfate $+\mathrm{L} 2$ basal medium.

yalues followed by different letters within a column differ at $P \leq 0.05$.

*** Significant at $P \leq 0.001$.

tablishment of these 11 species. Some shoots of each species rooted spontaneously on hormone-free MS medium; however, most species showed increased rooting frequencies after exposure to auxin (Table 6). Axillary shoots rooted in vitro are illustrated in Fig. 2 for P. knowltonii.
Re-establishment of all 11 species in the greenhouse was successfully achieved during the root development treatments described (Table 6). No significant phenotypic variation was observed among the propagules after 6 to 12 months of growth in the greenhouse. The size and quality of the re-established 
Table 5. Effect of combinations of auxins, cytokinins, and basal media on shoot production of four species of cacti during 3 months following micropropagation.

\begin{tabular}{|c|c|c|c|c|c|c|}
\hline & & \multicolumn{5}{|c|}{ Mean shoot number per monthly passagey } \\
\hline \multicolumn{2}{|c|}{ Auxin and cytokinin $^{z}$} & \multirow{2}{*}{$\begin{array}{c}\text { Escobaria } \\
\text { robbinsorum }\end{array}$} & \multirow{2}{*}{$\begin{array}{c}\text { Pediocactus } \\
\text { bradyi }\end{array}$} & \multirow{2}{*}{$\begin{array}{l}\text { Pediocactus } \\
\text { paradinei }\end{array}$} & \multirow{2}{*}{$\begin{array}{c}\text { Toumeya } \\
\text { papyracantha }\end{array}$} & \multirow{2}{*}{$\begin{array}{c}\text { Treatment } \\
\text { means }\end{array}$} \\
\hline Compounds & Concn $(\mu \mathrm{M})$ & & & & & \\
\hline \multicolumn{7}{|c|}{ L2 basal medium } \\
\hline Picloram & $0.0828+$ & & . & & & \\
\hline Zeatin & 45.6 & $2.3 \mathrm{~b}$ & $3.3 \mathrm{~b}$ & $6.3 \mathrm{a}$ & $2.8 \mathrm{bc}$ & 3.6 \\
\hline Picloram & $0.0828+$ & & & & & \\
\hline BA & 44.4 & $3.3 \mathrm{ab}$ & $4.6 \mathrm{ab}$ & $2.8 \mathrm{c}$ & $1.5 \mathrm{c}$ & 3.0 \\
\hline NAA & $1.1+$ & & & & & \\
\hline Zeatîn & 45.6 & $3.1 \mathrm{ab}$ & $4.5 \mathrm{ab}$ & $6.5 \mathrm{a}$ & $5.0 \mathrm{a}$ & 4.8 \\
\hline$N \wedge A$ & $1.1+$ & & & & - & \\
\hline BA & 44.4 & $3.8 \mathrm{ab}$ & $4.9 \mathrm{a}$ & $3.5 \mathrm{bc}$ & $2.5 \mathrm{c}$ & 3.7 \\
\hline \multicolumn{7}{|c|}{ MS basal medium } \\
\hline Picloram & $0.0828+$ & & & & & \\
\hline Zeatin & 45.6 & $4.3 \mathrm{a}$ & $5.4 \mathrm{a}$ & $5.7 \mathrm{a}$ & $2.7 \mathrm{bc}$ & 4.5 \\
\hline NAA & $1.1+$ & & & & $\ldots$ & \\
\hline $\begin{array}{c}\text { Zeatin } \\
\text { Species means }\end{array}$ & 45.6 & $\begin{array}{l}2.9 \mathrm{ab} \\
3.3\end{array}$ & $\begin{array}{l}5.0 \mathrm{a} \\
4.6\end{array}$ & $\begin{array}{l}5.1 \mathrm{ab} \\
5.0\end{array}$ & $\begin{array}{l}4.3 \mathrm{ab} \\
3.1\end{array}$ & 4.3 \\
\hline \multicolumn{2}{|c|}{ Source of variation } & \multicolumn{2}{|c|}{$\underline{\mathrm{df}}$} & \multicolumn{2}{|c|}{ Mean squares } & F value \\
\hline \multirow{2}{*}{\multicolumn{2}{|c|}{$\begin{array}{l}\text { Medium treatment } \\
\text { Species }\end{array}$}} & \multicolumn{2}{|c|}{5} & \multicolumn{2}{|c|}{28.04} & $5.40^{* * *}$ \\
\hline & & \multicolumn{2}{|c|}{3} & \multicolumn{2}{|c|}{82.78} & $15.95^{* * *}$ \\
\hline \multicolumn{2}{|c|}{ Medium treatment $\times$ species } & \multicolumn{2}{|c|}{15} & \multicolumn{2}{|c|}{17.57} & $3.39 * * *$ \\
\hline \multicolumn{2}{|c|}{ Error } & \multicolumn{2}{|c|}{72} & \multicolumn{2}{|c|}{5.19} & \\
\hline
\end{tabular}

${ }^{z}$ Auxin + cytokinin $+0.30 \mathrm{mM}$ adenine sulfate + basal medium as indicated.

y Values followed by different letters within a column differ at $P \leq 0.05$.

*** Significant at $P \leq 0.001$.

Table 6. Rooting of micropropagated shoots of 11 species of cacti and re-establishment of plantlets in the greenhouse in response to hormone treatment.

\begin{tabular}{|c|c|c|c|c|}
\hline \multirow[b]{2}{*}{ Species ${ }^{\mathbf{z}}$} & \multicolumn{3}{|c|}{ Shoots rooting (mean $\% \pm \mathrm{SE}$ ) } & \multirow{2}{*}{$\begin{array}{c}\text { Plantlets } \\
\text { re-established } \\
\text { (mean } \% \pm \mathrm{SE}) \\
\end{array}$} \\
\hline & No auxin ${ }^{y}$ & Auxin and concn $(\mu \mathrm{M})^{\mathrm{x}}$ & & \\
\hline $\begin{array}{l}\text { Escobaria missouriensis } \\
\text { Escobaria robbinsorum }\end{array}$ & $71 \pm 8$ & NAA (27) or IBA (25) & $90 \pm 3$ & $95 \pm 4$ \\
\hline $\begin{array}{l}\text { Mammillaria wrightii } \\
\text { Pediocactus knowltonii }\end{array}$ & $36 \pm 4$ & NAA (27) or IBA (25) & $64 \pm 9$ & $80 \pm 7$ \\
\hline $\begin{array}{l}\text { Pediocactus winkleri } \\
\text { Pediocactus bradyi } \\
\text { Pediocactus paradinei }\end{array}$ & $13 \pm 8$ & $\begin{array}{l}\text { NAA }(27) \text { or IBA }(25) \\
\text { or NAA }(54)+\text { IAA }(57)\end{array}$ & $45 \pm 4$ & $67 \pm 9$ \\
\hline $\begin{array}{l}\text { Pediocactus despainii } \\
\text { Sclerocactus mesae-verdae } \\
\text { Sclerocactus spinosior } \\
\text { Toumeya papyracantha }\end{array}$ & $3 \pm 2$ & $\begin{array}{l}\text { IBA }(25) \text { or } \\
\text { NAA }(54)+\text { IAA }(57)\end{array}$ & $7 \pm 2$ & $51 \pm 8$ \\
\hline
\end{tabular}

${ }^{z}$ Species are grouped for convenience of description of treatments and responses, and are listed in order of relative performance from best (top) to worst (bottom).

yRooting percentage after three 1-month passages on hormone-free MS medium.

xhooting percentage after 1 month on MS medium + auxin treatment as indicated, followed by 2 months on hormone-free MS.

plants is illustrated in Fig. 3 for P. bradyi. Micropropagated cactus plants appeared comparable in size and maturity to seedgrown plants several years old; e.g., M. wrightii flowered in the greenhouse during the summer following re-establishment, whereas seed-grown plants of this species normally require 3 to 5 years to reach maturity.

\section{Discussion}

In a micropropagation system, shoot number is the single most important variable to measure. However, the presence of callus may introduce the opportunity for spontaneous genetic mutation (Lee and Phillips, 1988), and callus production may represent a loss of shoot proliferation potential (Clayton, 1987). Shoot quality may also be an important measure of subsequent competency for re-establishment potential, as well as potential product value. Studies (Clayton, 1987) related to those reported here indicated that shoot quality, but not callus formation, was highly correlated with shoot number when used as response variables; assessments using combinations of these response variables may be useful for optimizing micropropagation systems for some species of cactus. Only the number of axillary shoots formed from each explant per passage is discussed in the 


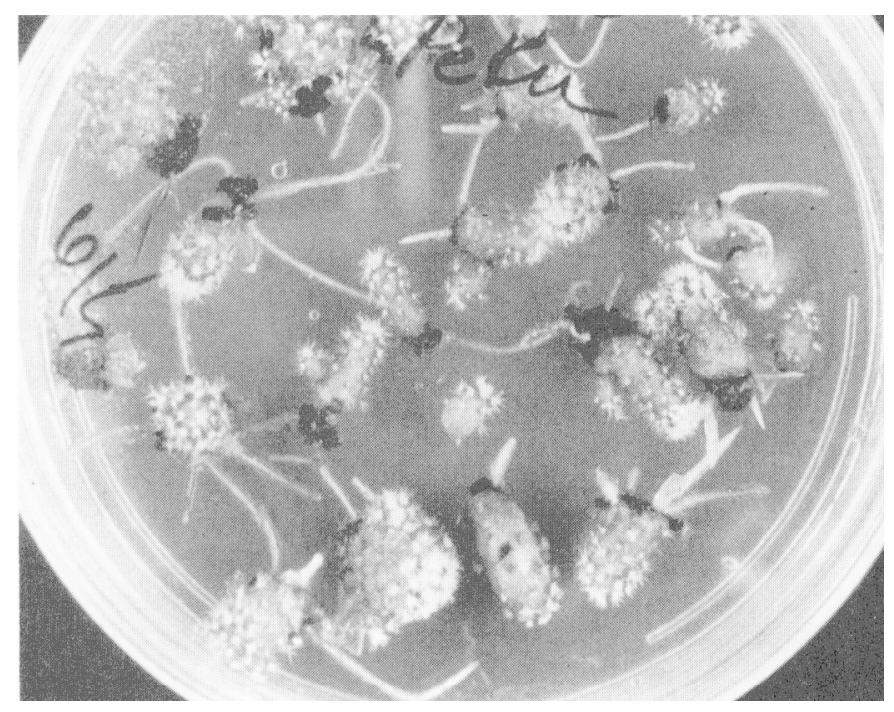

Fig. 2. Root development on hormone-free MS medium, following auxin treatment $(27 \mu \mathrm{M}$ NAA) in the previous passage, from micropropagated shoots of Pediocactus knowltonii.

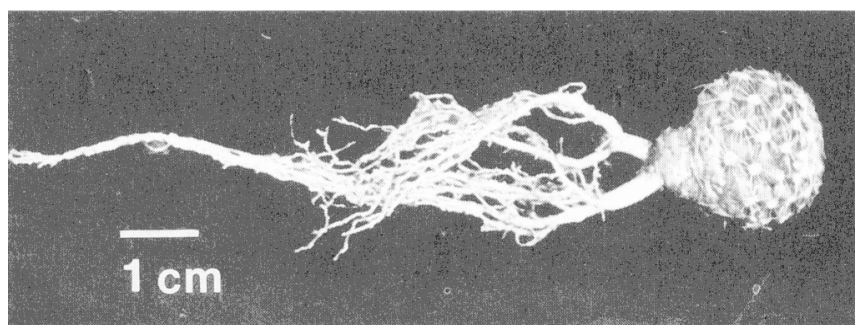

Fig. 3. Root system of re-established Pediocactus bradyi plant derived from tissue culture after 9 months of growth in the greenhouse.

present report. The highest rate of axillary shoot formation was observed for $P$. paradinei ( 9.8 shoots per explant per passage in the fourth experiment); while the lowest rate was observed for P. knowltonii (3.9 shoots per explant in the third experiment).

The MS basal medium has been widely used for cactus tissue cultures (Kolar et al., 1976; Johnson and Emino, 1979b; Escobar et al., 1986). However, researchers in cactus micropropagation had not evaluated this factor in detail. In the first experiment reported here, the most effective basal medium was L2, which differs from the other basal media tested in having the highest total major and minor salts concentrations, and in having a higher concentration of magnesium and calcium ions, which may be important for cactus nutrition. In contrast, the MMS medium containing half-strength major salts yielded the least satisfactory results, compared to the other four media typically categorized as high-salt media. However, the results of the fifth experiment indicated MS as well as L2 basal media can give satisfactory shoot proliferation cultures of cactus when the hormone combinations have been optimized. These results support the suggestion by Mauseth (1979) that any of the commonly used high-salt basal media may be suitable for establishing cactus micropropagation systems.

In evaluating auxin type and concentration as factors for axillary shoot proliferation in the second experiment, we found that treatments with no or low concentrations of auxin were more effective than those with high concentrations. However, results of the fourth experiment indicated the presence of low levels of auxin with cytokinin enhanced axillary shoot production in some species. To the best of our knowledge; cactus researchers had not previously evaluated this factor in detail for axillary shoot production. Some shoots of all 11 species subsequently rooted spontaneously on hormone-free medium; however, auxin treatments enhanced subsequent root induction frequencies for most species. These results confirm those of Mauseth (1979) and Ault and Blackmon (1987) concerning the role of auxin in cactus root development.

Zeatin was the most effective cytokinin type for axillary shoot proliferation from all four species in the third experiment. There was a strong interaction between the other cytokinin sources with species. Cytokinin is considered essential for development of cactus axillary shoots (Mauseth, 1979; Johnson and Emino, 1979b; Escobar et al., 1986).

In four of the five experiments conducted in this study, interaction effects between species and tissue culture factors were significant. In the fifth experiment, the treatments including 45.6 $\mu \mathrm{M}$ zeatin + 1.1 $\mu \mathrm{M}$ NAA, with either L2 or MS, were proven most effective for all four species evaluated. However, in the fourth experiment evaluating four different species, this same treatment using L2 was most effective for only one species. The treatments including $\mathrm{L} 2+22.8 \mu \mathrm{M}$ zeatin, with or without 1.1 $\mu \mathrm{M}$ NAA, were each effective for three of the four species in the fourth experiment. Thus, a single culture medium may not be suitable for optimal shoot proliferation of several genera of cacti. These results support the suggestion made by Johnson and Emino (1979a; 1979b) that the optimal hormone combination may be unique for each cactus species. However, the results of the fourth and fifth experiments of the present study, considered together, suggest that a group of three related media can be used to elicit optimal shoot proliferation responses from a number of cactus species.

The cacti micropropagated in this study are among those more difficult to propagate using conventional procedures. Micropropagated cacti can supply the commercial trade with difficult-to-propagate species. Conservation efforts involving outplantings of threatened or endangered cacti can be facilitated through micropropagation of several discrete clones sampled from native populations. Micropropagation also can be used in germplasm preservation for future study and use of rare, threatened, or endangered cacti.

\section{Literature Cited}

Ault, J.R. and W.J. Blackmon. 1985. In vitro propagation of selected native cacti species. HortScience 20:541. (Abstr.)

Ault, J.R. and W.J. Blackmon. 1987. In vitro propagation of Ferocactus acanthodes (Cactaceae). HortScience 22:126-127.

Clayton, P.W. 1987. Micropropagation as a means of conservation and commercialization of members of the subtribe Cactinae (Cactaceae). MS Thesis, New Mexico State Univ., Las Cruces.

Dunstan, D.I. and K.C. Short. 1977. Improved growth of tissue cultures of the onion, Allium cepa. Physiol. Plant. 41:70-72.

Escobar, H. A., V.M. Villalobos, and A. Villegas. 1986. Opuntia micropropagation by axillary proliferation. Plant Cell Tissue Organ Cult. 7:269-277.

Gamborg, O. L., R.A. Miller, and K. Ojima. 1968. Nutrient requirements of suspension cultures of soybean root cells. Expt. Cell Res. 50:151-158.

Gladfelter, H.J. and G.C. Phillips. 1987. De novo shoot organogenesis of Pinus eldarica Medw. in vitro: 1. Reproducible regeneration from long-term callus cultures. Plant Cell Rpt. 6:163-166. 
Havel, L. and Z. Kolar. 1983. Microexplant isolation from Cactaceae. Plant Cell Tissue Organ Cult. 2:349-353.

Johnson, J.L. and E.R. Emino. 1979a. In vitro propagation of Mammillaria elongata. HortScience 14:605-606.

Johnson, J.L. and E.R. Emino. 1979b. Tissue culture in the Cactaceae. Cact. Succ. J. (U. S.) 51:275-277.

King, M.R. 1957. Studies in the tissue culture of cacti. Cact. Succ. J. (U. S.) 29:102-104.

Kolar, Z., J. Bartek, and B. Vyskot. 1976. Vegetative propagation of the cactus Mammillaria woodsii through tissue cultures. Experiential 32:668-669.

Lee, M. and R.L. Phillips. 1988. The chromosomal basis of somaclonal variation. Annu. Rev. Plant Physiol. Mol. Biol. 39:413-437.

Mauseth, J.D. 1979. A new method for the propagation of cacti: sterile culture of axillary buds. Cact. Succ. J. (U. S.) 51:186-187.

Mauseth, J.D. and W. Halperin. 1975. Hormonal control of organogenesis in Opuntia polyacantha (Cactaceae). Amer. J. Bet. 62:869877.

Minocha, S.C. and P.N. Mehra. 1974. Nutritional and morphogenetic investigations of callus cultures of Neomammillaria prolifera Miller (Cactaceae). Amer. J. Bet. 61:168-173.

Murashige, T. and F. Skoog. 1962. A revised medium for rapid growth and bioassays with tobacco tissue cultures. Physiol. Plant. 15:473497.

Phillips, G.C. and G.B. Collins. 1979. In vitro tissue culture of selected legumes and plant regeneration of red clover. Crop Sci. 19:5964.

Rubluo, A., V. Chavez, O. Martinez, and A. Martinez, 1986. The recovery of endangered Mexican plant population through tissue culture, p. 428. In: D.A. Somers, B.G. Gengenbach, D.D. Biesboer, W.P. Hackett, and C.E. Green (eds.). VI Intl. Congr. Plant Tissue Cell Culture Abstr. Univ. of Minnesota, Minneapolis.

SAS Institute, Inc. 1982. SAS user's guide: Statistics. SAS Institute, Cary, N.C.

Schenk, R.U. and A.C. Hildebrandt. 1972. Medium and techniques for induction and growth of monocotyledonous and dicotyledonous plant cell cultures. Can. J. Bet. 50:199-204.

Sluis, C.J. and Z.S. Wochok. 1980. In vitro propagation of an endangered Pediocactus species. Plant Physiol. 65: S-36. (Abstr.)

Starling, R..J. 1985. In vitro propagation of Leuchtenbergia principis. Cact. Succ. J. (U. S.) 57:114-115.

Vyskot, B. and Z. Jara. 1984. Clonal propagation of cacti through axillary buds in vitro. J. Hort. Sci. 59:449-452. 